\title{
TEKNIK VOLTAMETRI PELUCUTAN ANODIK MENGGUNAKAN ELEKTRODA GLASSI KARBON DALAM PENENTUAN KADAR LOGAM FE DALAM TERONG UNGU
}

\author{
Irdhawati Irdhawati*, Vivi Eka Indrayani, Emmy Sahara \\ Program Studi Kimia Fakultas Matematika dan Ilmu Pengetahuan Alam Universitas Udayana, Kampus \\ Bukit Jimbaran Bali 80361 \\ *email: irdhawati@unud.ac.id
}

Received 3 September 2019

Accepted 31 December 2019

\begin{abstract}
Abstrak
Terong ungu adalah salah satu jenis tanaman yang banyak dibudidayakan. Tingginya permintaan terong menyebabkan petani menggunakan pupuk dan pestisida dari bahan kimia untuk meningkatkan produksi. Penggunaan bahan kimia yang berlebihan dapat mencemari lingkungan. Dalam penelitian ini kadar logam $\mathrm{Fe}$ dalam terong ungu ditentukan dengan teknik voltammetry pelucutan anodik. Elektroda kerja yang digunakan adalah glassi karbon, $\mathrm{Ag} / \mathrm{AgCl}$ sebagai elektroda pembanding, dan kawat platina sebagai elektroda lawan. Parameter pengukuran yang dioptimasi meliputi waktu deposisi, potensial deposisi, dan laju pindai. Selanjutnya dilakukan validasi rentang konsentrasi linier, limit deteksi, limit kuantisasi, keberulangan, dan perolehan kembali. Hasil yang diperoleh yaitu waktu deposisi optimum selama 40 detik, potensial deposisi optimum pada $-0,27 \mathrm{~V}$, serta laju pindai 2,5 mV/s. Liniearitas larutan standar Fe berada pada rentang 5 sampai $100 \mu \mathrm{g} / \mathrm{L}$, dengan koefisien korelasi 0,9964. Limit deteksi dan limit kuantisasi berturut-turut $18,36 \mu \mathrm{g} / \mathrm{L}$ dan $37,79 \mu \mathrm{g} / \mathrm{L}$. Keberulangan pengukuran menghasilkan nilai rasio Horwitz $<2$. Perolehan kembali standar logam Fe yang ditambahkan ke dalam larutan sampel diperoleh $100,00 \pm 0,07 \%$. Kadar Fe dalam terong ungu pada kondisi pengukuran optimum diperoleh $80,40 \pm 1,85 \mu \mathrm{g} / \mathrm{kg}$. Nilai tersebut lebih kecil dari Standar Nasional Indonesia (SNI) untuk kadar logam dalam bahan pangan yaitu $5000 \mu \mathrm{g} / \mathrm{kg}$.
\end{abstract}

Kata kunci: logam Fe, voltametri pelucutan anodik, terong ungu, elektroda glassi karbon

\begin{abstract}
Purple eggplant is one type of plant that is widely cultivated. The high demand for eggplants causes farmers to use fertilizers and pesticides from chemicals to increase production. Excessive use of chemicals can pollute the environment. In this study the content of $\mathrm{Fe}$ in purple eggplant were determined by anodic stripping voltammetry technique. The working electrode was glassy carbon, $\mathrm{Ag} / \mathrm{AgCl}$ as the reference electrode, and platinum wire as the counter electrode. Optimized measurement parameters included deposition time, deposition potential and scan rate. The linear concentration range, detection limit, quantization limit, repeatability, and recovery are validated. The results were obtained the optimum deposition time of 40 seconds, optimum deposition potential at $-0.27 \mathrm{~V}$, and scan rate of $2.5 \mathrm{mV} / \mathrm{s}$. Linearity of standard Fe solutions was in the range of 5 to $100 \mu \mathrm{g} / \mathrm{L}$, with a correlation coefficient of 0.9964 . Detection limits and quantization limits were $18.36 \mu \mathrm{g} / \mathrm{L}$ and $37.79 \mu \mathrm{g} / \mathrm{L}$, respectively. Repeatability measurements result had value of Horwitz ratio $<2$. The recovery of the standard Fe added to the sample solution was obtained $100.00 \pm 0.07 \%$. Fe content in purple eggplant
\end{abstract}


was obtained $80.40 \pm 1.85 \mu \mathrm{g} / \mathrm{kg}$. This value is smaller than the Indonesian National Standard (SNI) for metal content in food of $5000 \mu \mathrm{g} / \mathrm{kg}$.

Key words: iron, anodic stripping voltammetry, eggplant, glassy carbon electrode

\section{Pendahuluan}

Tanaman terong ungu merupakan salah satu jenis sayuran yang banyak diminati masyarakat. Untuk menjaga kualitas, meningkatkan hasil produksi, dan meminimalisir gagal panen tanaman terong ungu, para petani menggunakan pupuk dan pestisida sintesis secara rutin. Penggunaan pupuk dan pestisida yang berlebihan secara tidak langsung dapat mencemari tanah dan tanaman karena pestisida dan pupuk mengandung sejumlah logam dalam konsentrasi yang berbeda-beda (Alloway, 2013). Adanya logam berat dalam tanah dapat menurunkan kualitas hasil produksi dan dapat terserap oleh tanaman kemudian akan masuk ke dalam siklus rantai makanan dan membahayakan kesehatan masyarakat. Logam berat dapat terakumulasi dalam tubuh manusia dan jika melebihi kadar maksimum akan menimbulkan efek toksik (Duruibe et al, 2007).

Logam Fe adalah logam esensial dibutuhkan tanaman dalam proses pertumbuhan. Walaupun bersifat esensial, dalam jumlah yang lebih dari $5 \mathrm{mg} / \mathrm{L}$ (BSN, 2009) dapat mengganggu pertumbuhan. Teknik yang dapat digunakan untuk menganalisis logam adalah voltametri pelucutan anodik, yaitu teknik voltametri pelucutan anodik pulsa diferensial (Differential Pulse Anodic Stripping Voltammetry-DPASV). Teknik ini memiliki limit deteksi rendah, penyiapan sampel mudah, waktu analisis cepat, kadar logam dalam sampel dapat ditentukan secara simultan, dan biaya yang relatif murah (Settle, 1997; Gunzler and Williams, 2001; Zosky (2007); dan Ardini et al, 2010).

Kinerja teknik voltametri dipengaruhi oleh elektrode kerja (Wang, 2001). Irdhawati et al (2018) telah menggunakan teknik voltametri pelucutan anodik pulsa diferensial dalam pengukuran kadar logam $\mathrm{Fe}(\mathrm{III})$ dengan elektroda kerja glassi karbon pada tanaman pakcoy diperoleh waktu deposisi optimum 70 detik, laju pindai optimum 10 $\mathrm{mV} / \mathrm{s}$, serta potensial deposisi optimum 0.47 V. Hasil pengukuran validitas diperoleh rentang konsentrasi linier dari $50 \sim 500 \mu \mathrm{g} / \mathrm{L}$, dengan nilai koefisien korelasi 0,9977, limit deteksi 50,18 $\mu \mathrm{g} / \mathrm{L}$, dan uji keberulangan pengukuran mempunyai rasio Horwitz lebih kecil dari 2. Persen perolehan kembali $100,26 \% \pm$ $0,27 \%$. Hasil pengukuran rata-rata $\mathrm{Fe}(\mathrm{III})$ pada sampel tanaman pakcoy dari lima titik lokasi sampling di daerah Bedugul Bali sebesar 3,82 $\pm 0,29 \mathrm{mg} / \mathrm{L}$. Penelitian lain telah dilakukan oleh Sari (2016) yang menentukan kadar Fe dalam kangkung air dari muara sungai Badung menggunakan metode voltammetri pelucutan anodic gelombang persegi, diperoleh kondisi optimum pada waktu deposisi 150 detik dan laju pindai $5 \mathrm{mV} / \mathrm{s}$. Hasil validasi pengukuran dengan larutan standar $\mathrm{Fe}(\mathrm{III})$, linearitas berada pada rentang 50 $\sim 500 \mu \mathrm{g} / \mathrm{L}$ dengan koefisien korelasi 0,9973. Nilai limit deteksi adalah 44 $\mu \mathrm{g} / \mathrm{L}$, rasio Horwitz $<2$, dan persen perolehan kembali $(99,45 \pm 0,02) \%$. Uji sampel kangkung air yang telah didestruksi dengan aqua regia diperoleh kadar Fe(III) sebesar $26,5 \mathrm{mg} / \mathrm{kg}$.

$$
\text { Untuk menguji metode }
$$
voltammetri yang digunakan, maka perlu dilakukan optimasi kondisi dan validasi pengukuran. Parameter yang dioptimasi meliputi waktu deposisi, potensial deposisi, dan laju pindai, sedangkan parameter validasi yaitu rentang konsentrasi linier, limit deteksi, limit kuantisasi, keberulangan pengukuran, dan persen perolehan kembali. Parameter 
tersebut menjadi ukuran dari kemampuan metode untuk mengidentifikasi analit. Pada penelitian ini, analisis kadar $\mathrm{Fe}$ dalam tanaman terong ungu dilakukan menggunakan teknik voltammetri pelucutan anodik pulsa diferensial, dengan elektrode kerja berupa glassi karbon.

\section{Metode Penelitian}

\section{Alat dan Bahan}

Potensiostat Ingsens 1030, adaptor, neraca analitik Shimadzu Tipe ATY224, elektrode kerja glassi karbon diameter 2,0 $\mathrm{mm}$ dari Bio Analytical System (BAS), elektrode pembanding $\mathrm{Ag} / \mathrm{AgCl}$ (handmade), elektrode lawan kawat platina diameter $0,5 \mathrm{mM}$, pipet mikro (Socorex), pengaduk magnetik, polishing sheet, oven (Memmert), metal block digester $Z X$, mortar, alu, dan peralatan gelas.

Bahan-bahan yang digunakan yaitu $\mathrm{HNO}_{3}, \mathrm{HCl}, \mathrm{FeCl}_{3} \cdot 6 \mathrm{H}_{2} \mathrm{O}, \mathrm{K}_{3} \mathrm{Fe}(\mathrm{CN})_{6}$, $\mathrm{K}_{4} \mathrm{Fe}(\mathrm{CN})_{6} .3 \mathrm{H}_{2} \mathrm{O}$, aqua regia (campuran $\mathrm{HNO}_{3}: \mathrm{HCl}=1: 3$ ), $\mathrm{KCl}$, bubur alumina $0.05 \mu \mathrm{m}$, aseton, aquabides. Semua bahan kimia yang digunakan dibeli dari Merck dengan kualitas pro analisis, tanpa pemurnian tambahan.

Prosedur Penelitian

Optimasi kondisi pengukuran

a) Penentuan waktu deposisi optimum

Pengukuran dilakukan dengan variasi waktu deposisi 20;40;60;80 dan 100 detik dengan kecepatan pengadukan 2000 rpm, waktu diam (quiet time) 25 detik, rentang potensial $-1,4 \mathrm{~V}$ sampai $+0,4 \mathrm{~V}$, potensial deposisi $-1,3 \mathrm{~V}$ dan laju pindai $10 \mathrm{mV} / \mathrm{s}$.

b) Penentuan potensial deposisi optimum

Variasi potensial deposisi yaitu $-0,17$; 0,$27 ; \quad-0,37 ; \quad-0,47 ; \quad-0,57 \quad \mathrm{~V}$ dengan kecepatan pengadukan $2000 \mathrm{rpm}$, waktu diam (quiet time) 25 detik, rentang potensial $-1,4 \mathrm{~V}$ sampai $+0,4 \mathrm{~V}$, dan laju pindai $10 \mathrm{mV} / \mathrm{s}$, dan waktu deposisi dari hasil pengukuran pada prosedur (a).

c) Penentuan laju pindai optimum
Variasi laju pindai 1,$25 ; 2,00 ; 2,50 ; 3,75$; 5,00 dan $6,25 \mathrm{mV} / \mathrm{s}$ dengan kecepatan pengadukan $2000 \mathrm{rpm}$, waktu diam (quiet time) 25 detik, rentang potensial $-1,4 \mathrm{~V}$ sampai $+0,4 \mathrm{~V}$, waktu dan potensial deposisi sesuai hasil pada prosedur (a) dan (b).

\section{Validasi Pengukuran}

a) Penentuan rentang konsentrasi linier Rentang konsentrasi linier ditentukan dengan mengukur arus puncak dari larutan standar dengan konsentrasi: 5; 10; $25 ; 50 ; 100 ; 250 ; 500 ; 1000 ; 1500 ; 2000$; $2500 \mu \mathrm{g} / \mathrm{L}$ menggunakan pelarut $\mathrm{HCl} 0,1$ M . Selanjutnya dibuat plot antara arus puncak yang terukur (y) terhadap konsentrasi larutan (x).

b) Penentuan limit deteksi dan limit kuantisasi

Limit deteksi dan limit kuantisasi ditentukan berdasarkan data rentang konsentrasi linier dan perhitungan menggunakan persamaan 1, 2, 3 dan 4 (Miller and Miller, 2010).

$$
\begin{aligned}
& \quad S y / x=\sqrt{\frac{\sum\left(y_{i}-\hat{y}_{i}\right)^{2}}{n-2}} \\
& \hat{y}_{i}=a+b x \\
& L o D=\frac{3 S y / x}{b} \\
& L o Q=\frac{10 S y / x}{b}
\end{aligned}
$$

Keterangan:

Sy/x =standar deviasi terhadap garis linier

$\mathrm{b} \quad=$ slope $/$ kemiringan

LoD = limit deteksi

a $\quad=$ intersep

Nilai $\hat{y}_{i}$ pada standar deviasi diperoleh dengan memasukkan nilai $\mathrm{x}$ dalam persamaan regresi linier

c) Penentuan keberulangan pengukuran (ketelitian)

Ketelitian pengukuran ditentukan dengan mengukur arus yang dihasilkan oleh larutan standar $\mathrm{Fe}$ dengan konsentrasi 50 $\mu \mathrm{g} / \mathrm{L}$ dalam $\mathrm{HCl} 0,1 \mathrm{M}$ pada kondisi pengukuran optimum yang dilakukan 
secara berulang sebanyak sepuluh kali pengukuran. Koefisien variansi (CV) dari hasil pengukuran sebanyak sepuluh kali dihitung kemudian dibandingkan dengan CV Horwitz, sehingga diperoleh nilai Horwitz Ratio (Horrat). Keberulangan dapat diterima jika nilai Horrat lebih kecil dari dua (Horwitz and Albert, 2006).

d) Penentuan persen perolehan kembali (\% recovery)

$\%$ Recovery $=\frac{\text { (konsentrasi sampel }+ \text { standar })-(\text { konsentrasi sampel })}{\text { konsentrasi standar }} \times 100 \%$
Persen perolehan kembali ditentukan dengan metode standar adisi. Larutan sampel diukur sehingga diperoleh arus puncak, kemudian ditambahkan standar Fe $50 \mu \mathrm{g} / \mathrm{L}$ sebanyak $1,00 \mathrm{~mL}$. Larutan dengan komposisi yang sama dibuat tiga kali kemudian arus yang terbentuk diukur. Persen perolehan kembali dihitung menggunakan Persamaan 5.

\section{Preparasi dan pengukuran konsentrasi} Fe dalam sampel

Sampel terong ungu dicuci dengan air bersih, dibilas dengan aquabides, kemudian dikeringkan selama 24 jam pada suhu kamar. Sampel diiris tipis dan dipotong kecil dengan ukuran \pm 1 x $1 \mathrm{~cm}$, ditimbang, dan dikeringkan dalam oven pengering suhu $80{ }^{\circ} \mathrm{C}$. Sampel ditimbang lagi hingga diperoleh massa konstan, sehingga kadar air sampel dapat ditentukan. Sampel kering dihaluskan, lalu ditimbang dan didestruksi menggunakan aqua regia dalam metal block digester pada suhu 120 ${ }^{0} \mathrm{C}$ selama 1 jam. Larutan hasil destruksi disaring, dan filtrat diencerkan hingga 50,0 mL.

Penentuan konsentrasi $\mathrm{Fe}$ dalam sampel menggunakan metode adisi standar. Sebanyak $2.0 \mathrm{~mL}$ larutan sampel hasil destruksi dimasukkan masingmasing ke dalam lima buah labu ukur $10,0 \mathrm{~mL}$ dengan komposisi volume larutan standar sebanyak 0,00;0,40;0,60; 1,00 dan 1,60 mL, dan ditambahkan $\mathrm{HCl}$ $0,1 \mathrm{M}$ hingga tanda batas, dan dikocok hingga homogen. Kadar Fe dalam sampel ditentukan pada kondisi pengukuran optimum.

\section{Hasil dan Pembahasan \\ Optimasi Kondisi Pengukuran \\ Optimasi waktu deposisi}

Hasil pengukuran larutan standar Fe dengan waktu deposisi yang bervariasi terdapat pada Gambar 1. Adanya perbedaan nilai arus puncak pada waktu deposisi yang bervariasi menunjukkan bahwa waktu deposisi mempengaruhi arus puncak yang dihasilkan. Ini ditandai dengan arus puncak larutan standar yang mengalami peningkatan sebelum waktu deposisi optimum yaitu pada 20 dan 40 detik dan kemudian arus puncak menurun setelah melewati waktu deposisi 40 detik. Hal ini disebabkan karena pada waktu deposisi yang lebih kecil dari 40 detik, Fe belum jenuh terdeposisi di permukaan elektroda kerja. Arus puncak meningkat sampai terjadi kesetimbangan laju transfer elektron pada lapisan difusi di permukaan elektroda kerja. Pada waktu deposisi optimum, terjadi kesetimbangan reaksi redoks di permukaan elektroda kerja glassi karbon yang digunakan (Harvey, 2000). 


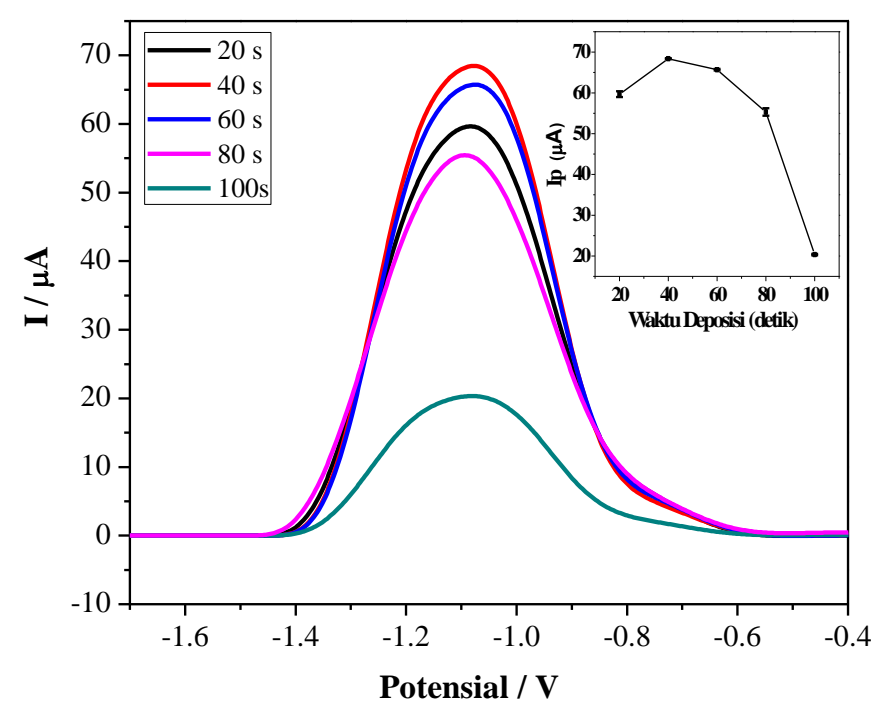

Gambar 1. Voltammogram pengukuran larutan standar Fe $500 \mu \mathrm{g} \mathrm{L}^{-1}$ dengan waktu deposisi bervariasi. Gambar inset adalah plot antara waktu deposisi terhadap arus puncak yang dihasilkan

\section{Optimasi potensial deposisi}

Pemberian potensial deposisi pada elektroda kerja glassi karbon adalah untuk membuat ion logam dapat terdeposisi pada permukaan elektroda kerja. Potensial reduksi standar $\mathrm{Fe}^{3+} / \mathrm{Fe}$ sebesar $-0,037 \mathrm{~V}$. Potensial yang diberikan harus lebih negatif minimal $100 \mathrm{mV}$ dari potensial reduksi standar agar ion dapat tereduksi dengan mudah (Wang, 2001). Hasil pengukuran optimasi potensial deposisi $\mathrm{Fe}(\mathrm{III}) 500 \mu \mathrm{g} / \mathrm{L}$ terdapat pada Gambar 2 . Dari hasil optimasi, diperoleh potensial deposisi optimum larutan standar Fe(III) $500 \mu \mathrm{g} / \mathrm{L}$ sebesar $-0,27 \mathrm{~V}$.

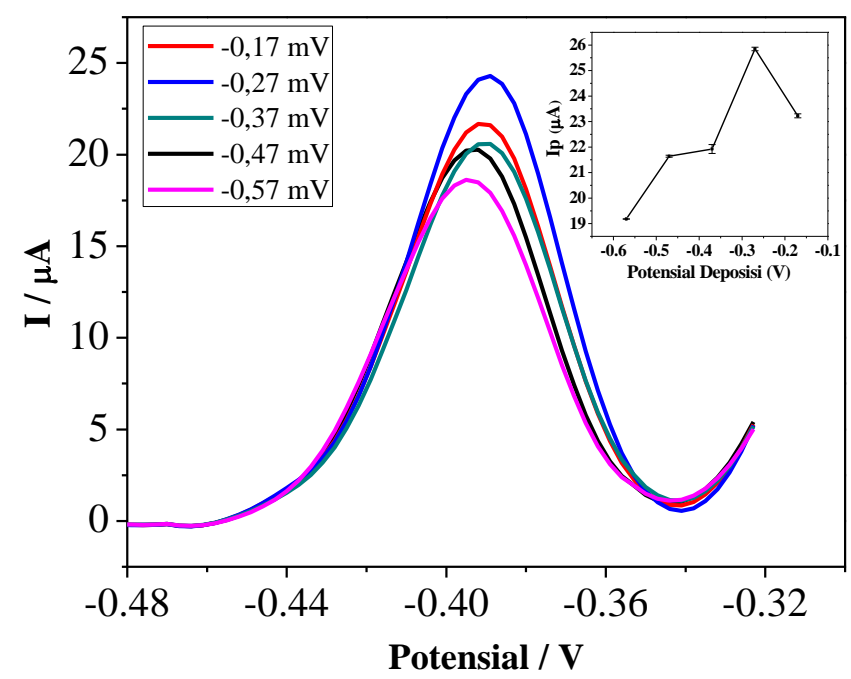


Gambar 2. Voltammogram pengukuran larutan standar Fe(III) $500 \mu \mathrm{g} \mathrm{L}^{-1}$ dengan potensial deposisi yang bervariasi, dan plot antara potensial deposisi dengan arus puncak yang dihasilkan

Optimasi laju pindai

Data voltamogram laju pindai larutan standar Fe(III) $500 \mu \mathrm{g} / \mathrm{L}$ ditunjukkan pada Gambar 3. Dari plot antara laju pindai dan arus puncak dapat diketahui laju pindai optimum untuk pengukuran Fe yaitu 2,5 mV/s . Laju pindai optimum berhubungan dengan laju transfer elektron ketika terjadi reaksi redoks pada permukaan elektroda.

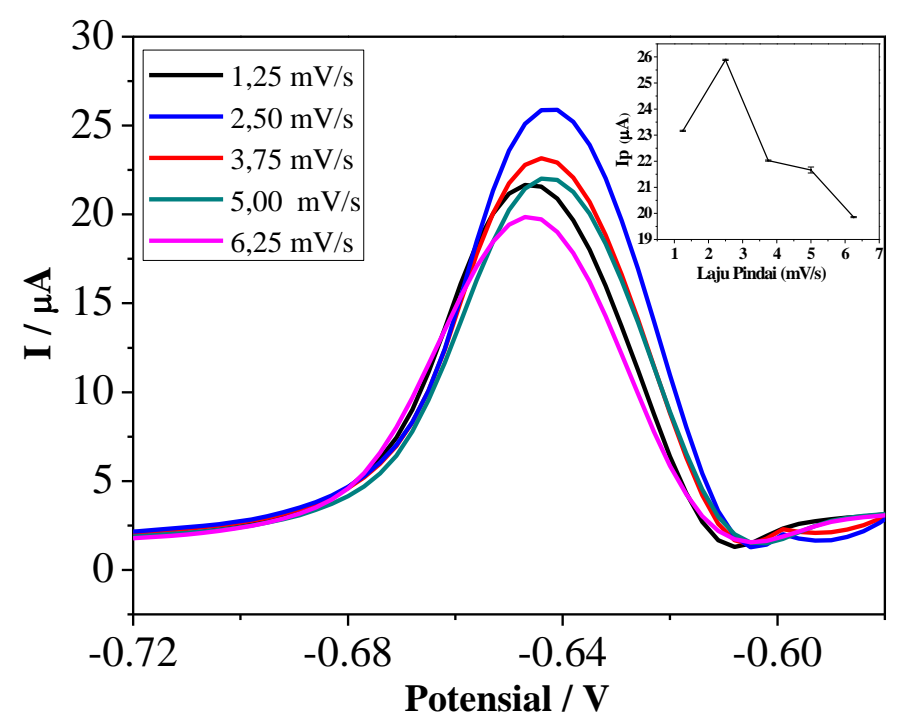

Gambar 3. Voltammogram optimasi laju pindai larutan standar Fe(III) $500 \mu \mathrm{g} \mathrm{L}$ ${ }^{1}$, dan plot antara laju pindai dan arus puncak

Validasi Pengukuran

Rentang konsentrasi linier

Linearitas pengukuran ditentukan dengan mengukur arus puncak larutan $\mathrm{Fe}$ pada rentang konsentrasi dari 5 sampai $2500 \mu \mathrm{g} / \mathrm{L}$. Dari hasil plot antara konsentrasi larutan dan arus puncak, diperoleh rentang yang linier, yaitu dari 5 $\sim 100 \mu \mathrm{g} / \mathrm{L}$. Arus puncak larutan standar dengan konsentrasi di atas $100 \mu \mathrm{g} / \mathrm{L}$ tidak linier lagi terhadap kenaikan konsentrasi.
Persamaan garis regresi pada rentang linier adalah $\mathrm{y}=0,1438 \mathrm{x}+20,6830$. Kenaikan arus puncak sebanding dengan kenaikan konsentrasi, sehingga memberi respon linier antara konsentrasi dengan arus puncak. Hubungan linier antara konsentrasi dengan arus puncak dibuktikan dengan nilai koefisien korelasi yang mendekati satu yakni 0,9964. Kurva kalibrasi larutan standar Fe(III) ditunjukkan pada Gambar 4. 


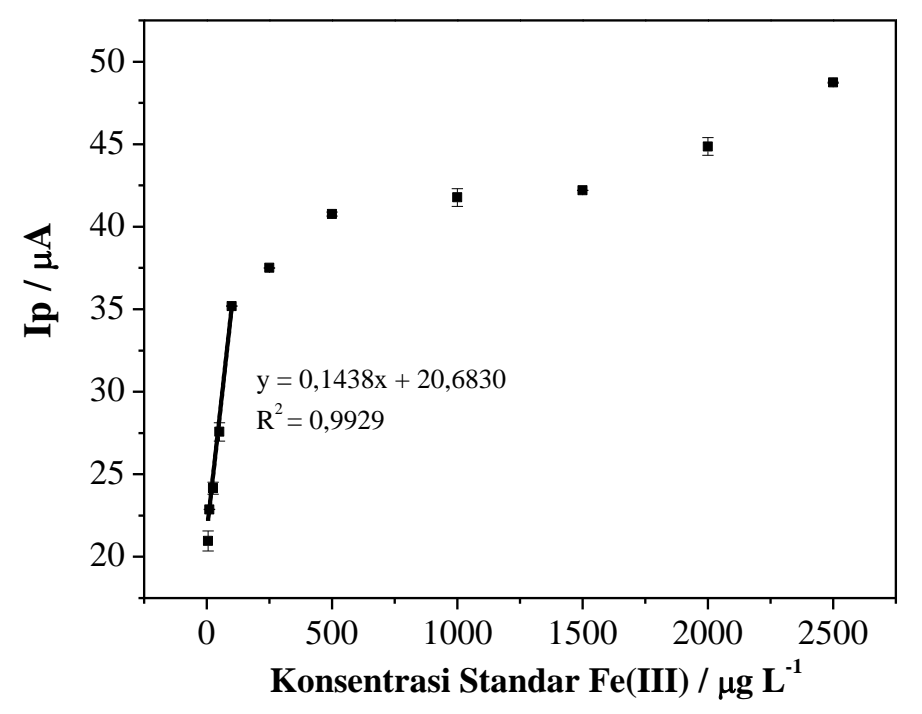

Gambar 4. Kurva kalibrasi pengukuran larutan standar Fe(III)

\section{Limit deteksi dan limit kuantisasi}

Limit deteksi menunjukkan konsentrasi terkecil analit yang dapat terdeteksi oleh instrumen, yang berbeda dengan blanko. Jika kadar ion logam dalam sampel lebih rendah dari limit deteksi, maka akan sulit untuk membedakan antara arus puncak yang dihasilkan oleh blanko dengan arus puncak dari analit. Limit deteksi larutan standar $\mathrm{Fe}(\mathrm{III})$ berdasarkan hasil perhitungan sebesar $11,34 \mu \mathrm{g} / \mathrm{L}$. Nilai tersebut menunjukkan bahwa pada konsentrasi yang lebih kecil dari 11,34 $\mu \mathrm{g} / \mathrm{L}$, arus puncak terukur tidak bisa dibedakan dengan respon larutan blanko.

Limit kuantisasi adalah jumlah terkecil analit dalam sampel yang mampu memenuhi kriteria cermat dan seksama dengan respon analitnya 10 kali lebih besar dibanding respon dari sinyal blanko. Limit kuantisasi hasil perhitungan sebesar $37,79 \mu \mathrm{g} / \mathrm{L}$.

Keberulangan pengukuran

Hasil pengukuran larutan standar Fe(III) $50 \quad \mu \mathrm{g} / \mathrm{L}$ sebanyak $10 \quad$ kali memiliki nilai simpangan baku 0,5655 , simpangan baku relative 0,0169 , koefisien variansi 1,70, dan rasio Horwitz 0,0719. Keberulangan pengukuran dapat diterima dengan baik jika nilai rasio Horwitz kurang dari dua (Horwitz and Albert, 2006). Data arus puncak pengukuran larutan $\mathrm{Fe}(\mathrm{III})$ dengan konsentrasi yang sama ditunjukkan pada Gambar 5. 


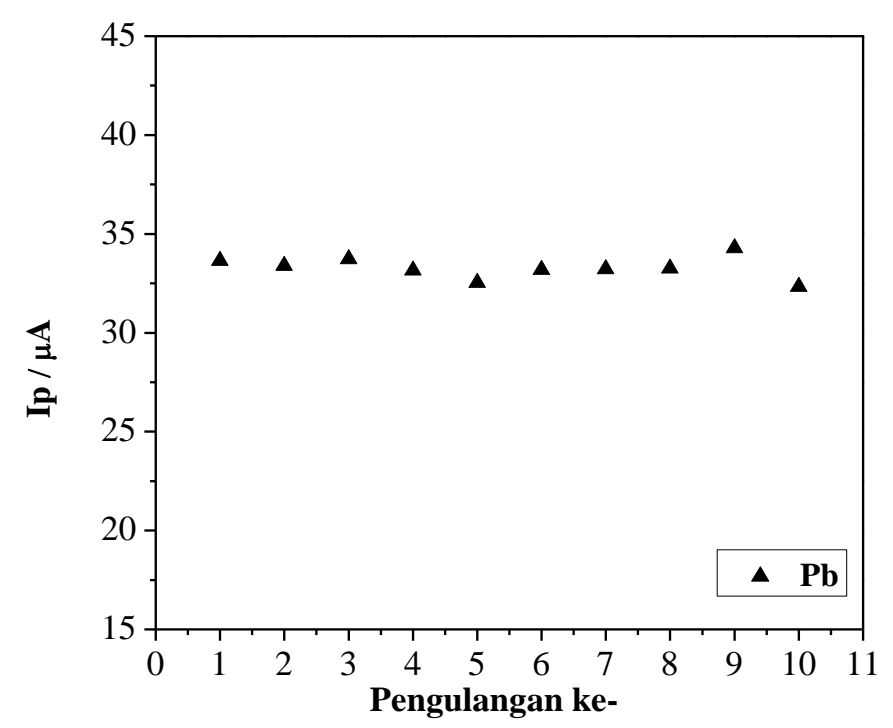

Gambar 5. Arus puncak pengukuran berulang larutan $\mathrm{Fe}(\mathrm{III}) 50 \mu \mathrm{g} \mathrm{L}^{-1}$ sebanyak sepuluh

\section{Persen perolehan kembali}

Persen perolehan

menunjukkan akurasi pengukuran instrumen terhadap nilai sebenarnya. Berdasarkan peraturan AOAC, 2010, nilai persen perolehan kembali yang dapat diterima untuk pengukuran analit berada pada rentang $80 \%$ sampai $110 \%$. Dari hasil pengukuran, diperoleh persen perolehan kembali Fe(III) sebesar 100,00 $\pm 0,07 \%$. Dengan demikian hasil pengukuran persen perolehan kembali dapat diterima.

Penentuan kadar air dan

logam Fe dalam sampel

Berdasarkan hasil perhitungan, kali

kadar air rata-rata pada terong ungu sebesar 55,55 $\pm 7,63 \%$. Penentuan kadar air bertujuan untuk mengetahui nilai gizi pangan sesuai dengan standar komposisi dan peraturan bahan pangan. Sampel yang sudah dihaluskan, selanjutnya didestruksi agar semua logam $\mathrm{Fe}$ yang berikatan dengan senyawa yang ada di dalam sampel dapat terputus dan semua persenyawaan $\mathrm{Fe}$ teroksidasi menjadi Fe(III). Kurva kalibrasi adisi standar pengukuran sampel ditunjukkan pada Gambar 6. 


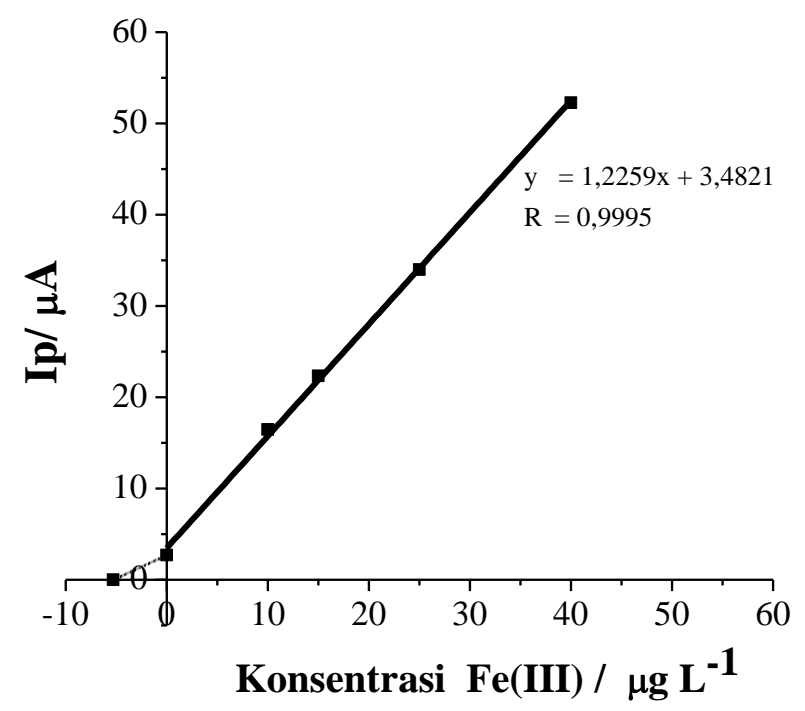

Gambar 6. Kurva kalibrasi penambahan standar larutan Fe(III) dalam sampel terong ungu

Dari hasil perhitungan diperoleh kadar $\mathrm{Fe}(\mathrm{III})$ yaitu $80,40 \pm 1,85 \mu \mathrm{g} / \mathrm{kg}$, yang tidak melebihi standar yang telah ditetapkan, yaitu $5 \mathrm{mg} / \mathrm{L}$ (BSN, 2009). Dengan demikian sayuran terong ungu yang ditanam oleh petani di Bedugul Bali mengandung logam $\mathrm{Fe}$, namun tidak melebihi kadar yang diperbolehkan. Pengawasan kualitas bahan pangan oleh pihak berwenang sangat diperlukan sebagai bentuk perlindungan konsumen. Edukasi kepada petani juga penting untuk meningkatkan pengetahuan tentang penggunaan pupuk dan pestisida sesuai kebutuhan.

\section{Kesimpulan}

Pengukuran $\mathrm{Fe}(\mathrm{III})$ menggunakan teknik voltametri pelucutan anodik pulsa diferensial dilakukan setelah optimasi waktu deposisi, potensial deposisi, dan laju pindai. Hasil validasi dengan menguji beberapa parameter diperoleh hasil yang dapat diterima, serta hasil analisis sampel pada kondisi pengukuran optimum tidak melebihi kadar yang diperolehkan oleh pemerintah.

\section{Ucapan Terima Kasih}

Penulis mengucapkan terima kasih kepada Bapak Mangku Rika sebagai pemilik kebun sayur tempat sampling terong ungu di Bedugul, Bali. Penelitian ini didanai oleh Kemenristekdikti dari Penelitian Dasar Unggulan Perguruan Tinggi (PDUPT) dengan nomor kontrak 492.44/UN14.4.A/LT/2019.

\section{Daftar Pustaka}

Alloway BJ, 2013, Heavy Metal in Soils:

Trace Metals and Metalloids in Soils and the Bioavailability, Springer, Berlin

AOAC (Association of Official Analytical Chemist), 2010, Official

Methods of Analysis of The Association of The Official Analytical Chemist, Washington D. C., USA

Arduini F, Calvo JQ, Palleschi G, Moscone D, Amine A. 2010. Bismuth Modified Electrodes for Lead Detection. Trends in Analytical Chemistry, 29(11); 12951304

Badan Standardisasi Nasional, 2009, "SNI:7387 Batas Maksimum Cemaran Logam Berat dalam Pangan”, BSN, Jakarta

Duruibe J.O., Ogwuegbu M.O.C. and 
Egwurugwu J.N., 2007, Heavy Metal Pollution and Human Biotoxic Effects, International Journal of Physical Sciences, 2007, 2 (5);112-118.

Gunzler H and Williams A, 2001, "Handbook of Analytical Techniques", Wiley-VCH-Verlag, Weinheim

Harvey, D., 2000, Modern Analytical Chemistry, McGraw-Hill, Singapore

Horwitz, W. and Albert RJ, 2006, The Horwitz Ratio (Horrat): A Useful Index Of Method Performance With Respect To Precision. J. AOAC. Int. 89(4): 1095-1109

Irdhawati, Mbatu, R.S.T, dan Sahara, E., 2018, Analisis Logam Fe dengan Teknik Voltammetry Pelucutan Anodik Pulsa Diferensial dalam Tanaman Pakcoy dari Perkebunan Sayur Bedugul Bali, Valensi, 4(2);168-173
Miller JN and Miller JC, 2010, Statistics and Chemometrics for Analytical Chemistry, Sixth Edition, Pearson Education Limited, England

Sari, L, 2016, Teknik Voltammetri Pelucutan Anodik Gelombang Persegi untuk Penentuan Kadar Logam $\mathrm{Pb}, \mathrm{Cu}$, dan $\mathrm{Fe}$ dalam Kangkung Air di Muara Sungai Badung, Skripsi, Universitas Udayana, Bukit Jimbaran

Settle F, 1997, Handbook of Instrumental Techniques for Analytical Chemistry", 1997, National Science Foundation, Arlington

Wang, J., 2001, Analytical Electrochemistry, $2^{\text {nd }}$ ed", John Willey \& Sons, New York

Zosky C, 2007, Handbook of Electrochemistry , Elsevier, Amsterdam 